\title{
The perception of elderly riverside residents of the Amazon region: the empirical knowledge that comes from rivers
}

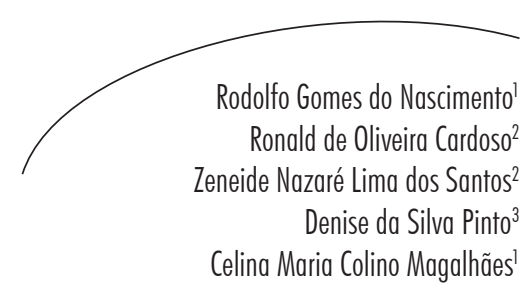

Abstract

Objective: To study and identify the perception of elderly riverside people of the Amazon region regarding old age. Method: An exploratory, descriptive, qualitative study was performed. Data was collected through interviews with 14 elderly riverside residents of the city of Cametá, Pará, Brazil. A script consisting of characterization data and an interview with semi-structured questions was used, guided by the following questions: "What is aging for you?" and "Is aging good or bad?". The participant observation technique was also used, through a field diary. For data analysis, we opted for thematic-categorical content analysis. Results: Generally, the elderly had a heterogeneous perception of old age. However, all saw it as a process anchored to the naturalness of life, as well as death. Some of the elderly persons associated old age with a phase of life with negative repercussions due to the appearance of functional disorders and limitations and especially the reduction of availability for work. It can be conferred that the majority, even with while displaying some limitations in this stage of life, have clear and well defined coping strategies, such as the recognition of their limitations or family and religious support. Conclusion: The study found that aging is the shared result of the experiences and knowledge of the interaction of the elderly persons with the riverside environment around them, resulting in their cultural differentiation.

\footnotetext{
Universidade Federal do Pará, Programa de Pós-graduação em Teoria e Pesquisa do Comportamento. Belém, Pará, Brasil.

2 Universidade do Estado do Pará, Centro de Ciências Biológicas e da Saúde, Programa de Residência Multiprofissional em Saúde. Belém, Pará, Brasil.

3 Universidade Federal do Pará, Instituto de Ciências da Saúde, Faculdade de Fisioterapia e Terapia Ocupacional. Belém, Pará, Brasil.
}

Key words: Aging; Elderly; Perception; Riverside Population. 


\section{INTRODUCTION}

An understanding of the aging process is anchored in multiple knowledge dimensions. ${ }^{1}$ The scientific representations of the nuances of this process, from a biopsychosocial perspective, are well documented in conceptual terms, and have emerged as important guidelines in the field of gerontology, providing tools for research and reinforcing healthcare.

Discussions on this theme have widened, leading to a subsequent growth in interest in researching and understanding the specifics of the process, including from other angles, such as the perspective of aging itself. ${ }^{2-8}$

What has been discovered through these approaches goes beyond the previously standardized and scientifically recognized dimensions on aging, resulting in extension in other directions, bringing scientific and popular knowledge closer together. Aging is now understood as "a series of morphological, physiological, biochemical and psychological changes that determine the progressive loss of an individual's adaptability to the environment", representing a universe of different valuations, representations and confrontations. Thus, new discussions and the possibility of a deeper reanalysis have emerged.

In this context it is worth mentioning some important theoretical frameworks on the aging process and how the elderly individual is perceived within it. In the view of Rodrigues \& Neri, ${ }^{10}$ aging implies a greater risk for the development of biological, socioeconomic and psychosocial vulnerabilities. In this context, it is associated with deficient conditions of education, income and health throughout life. To a greater or lesser degree, these vulnerabilities generate the possibility of illness and result in difficulties of access to the protective resources made available by society.

Moimaz et al. ${ }^{2}$ state that the elderly interpret the aging process in different ways and this is strongly influenced by the life history of each individual. In this way, Lima \& Murai ${ }^{7}$ and Paschoal ${ }^{11}$ corroborate and add that, as aging is not a homogeneous experience, each person experiences this phase of life in his or her own way, according to different standards, norms, expectations, desires, values and principles, taking into consideration the structural aspects of their lives, such as health, education and economic conditions.

Rodrigues \& Rauth ${ }^{12}$ go further, stating that "every person and every generation experiences old age differently, depending on a constellation of biological and environmental factors." In Brazil, it is also necessary to emphasize the importance of regional differences with regard to levels of health, education, opportunities and even life expectancy. For the authors "there is no single old age in Brazil, but rather a variety of old ages". ${ }^{12}$

In this context, the lack of studies on these perceptions involving the discourses of populations considered "vulnerable", such as riverside communities, represents a gap in literature. Little is known about old age in this context, which is typical of the Amazon region and is of considerable scientific interest. The aging process as experienced in these isolated environments, which have low levels of human development and poor healthcare and social protections, should be the subject of studies, as it is based on rich and extremely differentiated functional, social and cultural realities.

Given the above, it was considered necessary to discover how the aging process takes place in the remote riverside communities of the Amazon region, seeking to give greater visibility to this section of the population. This therefore study aimed to identify and analyze the perception of elderly riverside dwellers of the Amazon region regarding the aging process.

\section{METHOD}

An exploratory-descriptive study with a qualitative approach was carried out. The aim of the exploratory-descriptive study is to improve 
ideas, and it therefore features a highly flexible design which allows the investigation of various factor. The qualitative approach is concerned with the universe of meanings, reasons, aspirations, attitudes, beliefs and values, corresponding to a deep understanding of the relationships, processes and phenomena experienced by human beings. ${ }^{13,14}$

To ensure a deeper investigation of the subject, the instrumentation process was based on the interchange between the "semi-structured interview" and "participant observation" procedures. The semi-structured interviews were conducted by two researchers in the home of the elderly individuals. The interview script consisted of two parts: the first contained the demographic data of the respondent (gender, age, nationality, marital status, education, income, number of children and makeup of family); the second part contained semi-structured questions, directed by the following guiding questions: "What is aging for you?" "And is growing old good or bad?". The participant-observation technique involved creating a field diary record and allowed the explanatory dimensions of the data to be explored, and was carried out throughout each interview.

Data collection was performed in January 2015 and the defined field of study was the town of Cametá, located in the northeastern state of Pará, Brazil, $144 \mathrm{~km}$ in a straight line from the state capital of Belém. This city is the oldest and most historic urban area of the Lower Tocantins River, whose course is geographically shaped by around 90 river islands. According to the IBGE, the municipality has a population of 120,896 inhabitants, 3,800 of whom are aged over 60 years. ${ }^{15}$ The ecological context of the study involved two districts (the District of Juaba and the District of Carapajó), including seven islands that are remote from the town center and are accessible only by river transport (Tem-Tem, Mutuacá, Mutuacá de Baixo, Mutuacá de Cima, Mutuacazinho, Gama and Mapeuá).
The participants were 14 elderly residents native to the riverside communities, who were introduced to the researchers by two representatives (a native resident and a Community Health Agent). The criteria for the number of participants was the saturation of the speech content.

The elderly persons were approached individually and the research proposal and interest in hearing their opinions was explained. After they had accepted and signed Forms of Free and Informed Consent the interviews were conducted. It is worth noting that the interviews were carried out calmly, displaying interest and availability (without time limits) to the respondents, whilst also observing their non-verbal characteristics (Figure 1). The interviews were recorded with the aid of an audio-recorder and subsequently transcribed and typed in their entirety in Windows Word 2008.

Thematic analysis was chosen, with emphasis on the analysis of the thematic-categorical content. This analysis technique focuses on the meanings of communication, which serves as a basis for the inference of attributes or logical deductions and, finally, the categorization of themes. ${ }^{16}$ Operationally, three stages were followed: a) preanalysis; consisting of the initial reading, which allowed thorough contact with the collected material. The material was organized to respond to questions of validity, such as exhaustiveness, representativeness, homogeneity and relevance. At this stage, it was possible to determine the units of analysis (sentences), the hypotheses, the theoretical framework in which the results would be analyzed and the form of categorization; b) exploration of material; at this stage categorization was carried out. Sections of text in units of analysis were used and the data was aggregated, with the choice of the probable categories; c) processing and interpretation of results: a diagram featuring the categories of evidence was constructed to allow analysis and interpretation to be carried out and inferences to be drawn about the object of study - the perception of Amazonian riverine elderly persons on aging. 
The research project was approved by the Ethics Research Committee of the Núcleo de Medicina Tropical da Universidade Federal do Pará (the Tropical Medicine Center of Para Federal University), under registration $\mathrm{n}^{\circ} 926.744 / 2014$ (CAAE: 36972714.2.0000.5172). The elderly persons participated voluntarily and the study complied with Resolution $n^{\circ} 466 / 2012$ of the Ministry of Health.

\section{RESULTS AND DISCUSSION}

The study included 14 elderly riverside residents, aged between 64 and 96 years, with a mean age of 72.7 ( \pm 9.1$)$ years. The majority were male, married/ cohabiting and had no schooling. All lived in their own homes, with an average of 6.5 children, and cohabited mainly with their spouses, children and grandchildren (table 1).
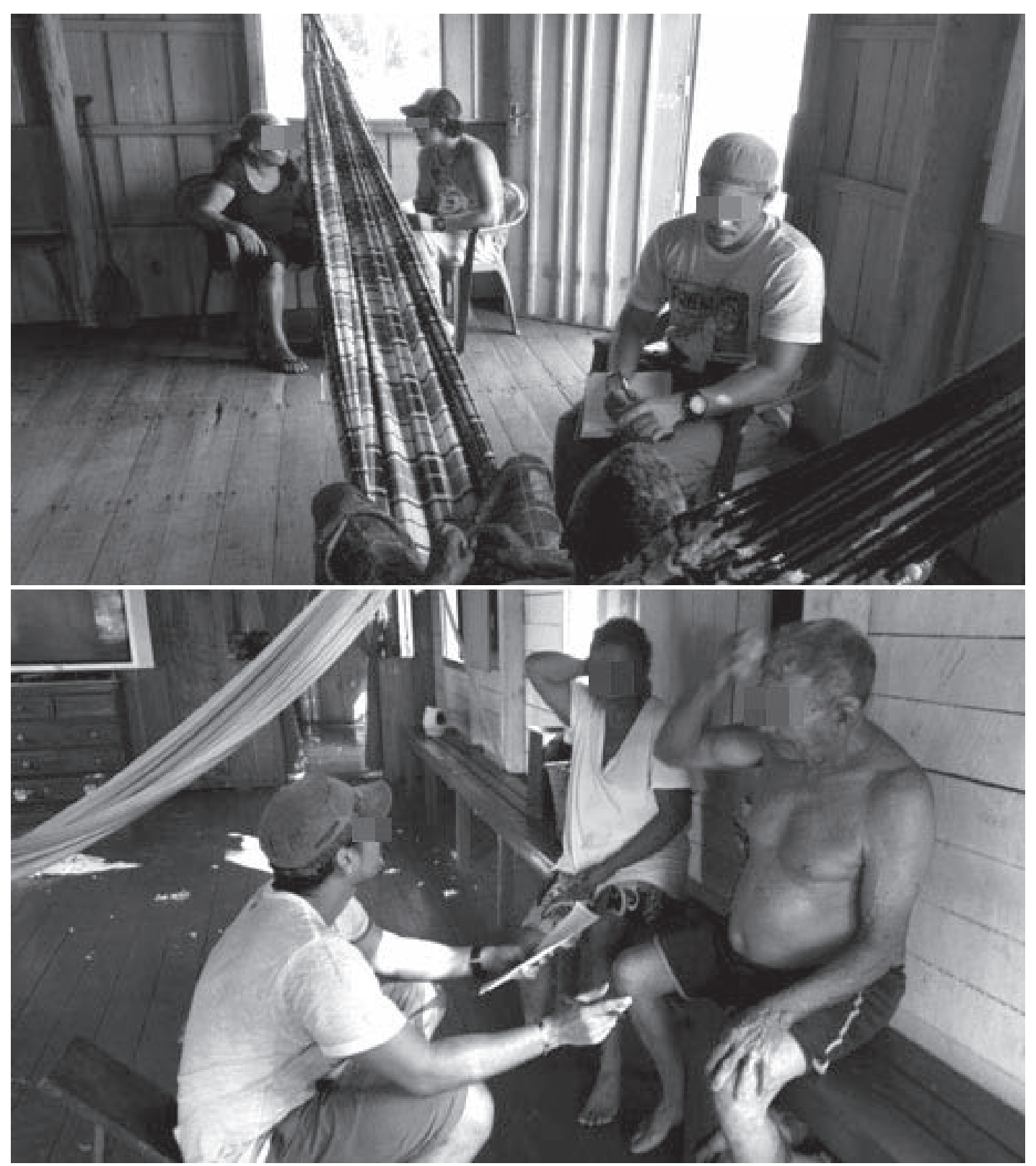

Figure 1. Photographs showing interviews with elderly individuals involved in the study. Cametá, Pará, 2015. 
Table 1. Sociodemographic profile of elderly riverside dwellers in the Amazon region. Cametá, Pará, 2015.

\begin{tabular}{|c|c|c|c|}
\hline Characteristics & $\mathrm{n}$ & $\%$ & CI95\% \\
\hline \multicolumn{4}{|l|}{ Gender } \\
\hline Female & 6 & 42.9 & 17.7-71.1 \\
\hline Male & 8 & 57.1 & $28.9-82.3$ \\
\hline \multicolumn{4}{|l|}{ Marital status } \\
\hline Married/cohabiting & 7 & 50.0 & $23.0-77.0$ \\
\hline Single & 4 & 28.6 & $8.4-58.1$ \\
\hline Widowed & 3 & 21.4 & 4.7-50.8 \\
\hline \multicolumn{4}{|l|}{ Education } \\
\hline None & 8 & 57.1 & $28.9-82.3$ \\
\hline 1 to 3 years & 4 & 28.6 & $8.4-58.1$ \\
\hline 4 to 7 years & 2 & 14.3 & $1.8-42.8$ \\
\hline \multicolumn{4}{|l|}{ Children } \\
\hline Yes & 12 & 85.7 & $57.2-98.2$ \\
\hline No & 2 & 14.3 & $1.8-42.8$ \\
\hline \multicolumn{4}{|l|}{ Family composition } \\
\hline Lives alone & 1 & 7.1 & $0.2-33.9$ \\
\hline Spouse with children/grandchildren & 6 & 42.9 & 17.7-71.1 \\
\hline Children/grandchildren & 4 & 28.6 & $8.4-58.1$ \\
\hline Other relations & 3 & 21.4 & $4.7-50.8$ \\
\hline
\end{tabular}

Historically, all the elderly persons were rural workers focused on family-based production, mainly through extractive farming and as fishermen. Their economic income was homogeneous, with the majority of respondents receiving income through the rural pension scheme, equivalent to the minimum wage, as well as potential additional income generated from extractive activities, such as selling fruit, especially açaí, and from animals reared and/or captured in the riverine environment (fish, shrimp, chicken and pigs).
Self-awareness of aging: giving a voice to elderly riverside dwellers

In general, talking about aging and old age with the elderly riverside dwellers was a very easy process. At first, the impression given was that everything was satisfactory, due to timidsounding responses such as "It's fine" and "It's not too bad" even with regard to the functional limitations and adversities of the environmental context where they lived. But as the conversations 
continued, the difficulties of their daily lives and their manners of coping were revealed wisely and in a very individual manner.

It should be noted that the various verbalized approaches in the discourses reflected the cultural influences of a long life in a shared environment that differs greatly from large urban centers, which reflected their differing needs, converging for the construction of the elderly biopsychosocial human being while retaining their individuality.

In accordance with the proposal of the study and following speech analysis, 179 units of analysis (sentences) emerged that allowed the categorization of topics and subtopics for evaluation. Through this process, it was possible to identify the meaning of old age for the elderly riverside dwellers through the references provided by them.

A. The perception that old age is anchored in a natural process: "Yes, it's good, parente (relative)", "You can't go back!”

When asked about their perceptions, different answers emerged, however, most of the elderly strongly and empirically indicated that aging was a natural process. This discourse, which employed a certain tone of conformism and/or acceptance, was of great interest to the researchers. Nevertheless, there were also echoes of nostalgia and comparisons with youth:

“[...] We don't have any choice, do we? But it's ok, if you have your health you bave all you need". (E11)

"Well, it's the way of getting old, isn't it? It's the way it is... You can't go back to your youth, can you?". (E3)

Souza et al. ${ }^{17}$ indicated that aging should be understood as a process of life. We grow old because we live, and often without realizing it. To Moimaz et al., ${ }^{2}$ what determines our capacity of acceptance and the manner in which we grow old is the individual behavior of each person. In the perception of the riverside elderly persons surveyed, aging is a part of human nature and is just a natural stage of life they are experiencing. They believe everyone will go through the same experience, regardless of the will of the individual, as verbalized by some:

$$
\begin{aligned}
& \text { "[...] I get by, it's good. It's one of those things, isn't } \\
& \text { it?". (E14) } \\
& \text { "It's good, because we can't say it's bad, can we [laughs]. } \\
& \text { It's aphase we have to go through. We have to go through } \\
& \text { it... Even if we don't want to". (E5) }
\end{aligned}
$$

Lima \& Murai ${ }^{7}$ observe that this process is universal, precisely because it is natural. For the authors, it is critical to understand that every living being is born, develops, grows, grows old and dies. Added to this perspective, it is also important to see old age as another phase of the process of human development rooted in transformations, challenges and confrontations, just as the other phases of the life cycle.

From the perspective of Zimerman, ${ }^{18}$ the elderly acquire a greater awareness of what they are experiencing when they accept and realize that aging is a natural process of the life cycle. Older people are then more likely to see old age positively, as a phase where they have accumulated the experience and maturity to allow them to be themselves, as well as freeing them of certain responsibilities.

However, although the elderly individuals surveyed perceived themselves as mature and experienced people, the imaginary meanings inferred in most of the discourses had negative echoes. The value allocated to activities that required good body functionality, such as working in agriculture and travelling in river vessels revealed the importance of their use and of being useful to the family and the community. Elderly persons, when they realize that their limitations, mainly resulting from physical aging, can free themselves from such responsibilities, may suffer a decline in their functionality and, therefore, their value as productive individuals. 


\section{B. Perception anchored in the repercussions of old age}

\section{B1. Processes of senility: "Avortado (Excess) of disease"}

The discourse of respondents revealed an aging marked by the onset of many diseases. Some of these were perceived by the elderly as the result of their own senility, in particular those linked to the locomotor, visual, gastrointestinal and cardiovascular systems. Others, however, denoted an unsuccessful aging process amid unfavorable social and economic conditions. For some of these elderly persons, old age is a time of living with pain and a feeling of incompetence in movement, which is expressed in their discourse with a certain sense of the mournful. The interface between old age and illness is sometimes so close that this stage of life is perceived as a pathological process itself, as noted:

$$
\text { "Look, old age is an illness....". (E3) }
$$

One peculiarity perceived in the statements of the elderly riverside dwellers is the strong association between diseases and functional and social repercussions. Thus, discussing the emergence of a pathological process was almost always accompanied by an increased focus on the limitations and on every day and occupational losses. Among the diseases mentioned, discourses in relation to changes in visual acuity, the gastrointestinal system and rheumatic processes, stood out, as shown in the following reports.

"[... these days I can't do many things at night because of my vision. When the motor stops, I can't even see with a lamp [...]”. (E13)

"[... I have dinner at 17.30 or $18 \mathrm{~h}$, because I can't eat at night, I have stomach trouble, so I have to have dinner early”. (E12)

".... I don't wash clothes because of rheumatism, my daughter does it. I can't sweep or clean the house, she does it [...]". (E10)
The emergence of new paradigms and values attributed to the aging process is closely linked to the environmental, socioeconomic and cultural context of the study. The riverside reality is strongly conditioned by physical strength and body resistance because of a life of long journeys and family subsistence labor, unlike the urban ecological context. Respondents revealed the impact of this burden, mainly related to a loss of strength and limitations in walking.

"[...] there are illnesses that mean you can't even walk [...] I used to be able to do a lot of things, but now I can't'. (E1)

"[...] I haven't stepped on the ground for almost two years now. My legs aren't good". (E8)

"[...] before, when I could, I'd go out, to visit my relatives. Before this my legs were strong [...]”. (E13)

"So now people tell me I can only get up to eat, I can't use too much strength, you know? That's what I'm telling you...It's not good because I can't do anything". (E12)

Moimaz et al. ${ }^{2}$ correctly highlighted that the terms movement and aging are closely linked. The importance of being able to move is not only related to the discovery of whether or not one is healthy, but also to autonomy, knowing one's own body and the aging process.

Salmaso et al. ${ }^{19}$ described sarcopenia, understood to mean a reduction in mass, muscle strength and power, as an important natural consequence of aging. Rizzoli et al. ${ }^{20}$ also added that this condition often correlates with functional decline and disability, and is considered one of the variables used to define the syndrome of frailty.

\section{B2. Functional limitations: "As much as you can"}

The verbal reports in this study reinforce the idea that old age, combined with pathological processes, can sometimes result in a fear of the individual losing overall functionality and control 
over his or her own existence. It is therefore worth highlighting the emergence of some symbolic representations of this situation:

"Well, as long as I can keep living and still know what I'm doing, you know? Because being stuck in a corner... There are people like that, aren't there? Who just want to stay alive! Aren't there? Who aren't dead yet, they're still alive, but they don't know what's going on, they can't do anything. To live like that, I don't think it's... no, it's not good'. (E2)

According to Moraes, ${ }^{21}$ well-being and functionality are equivalent; they represent the existence of autonomy (the individual capacity to make decisions and have control over one's actions, establishing and following one's own rules) and independence (ability to perform an activity by one's own means), allowing the individual to take care of themselves and their lives.

Reflecting on health and functionality, Moraes ${ }^{21}$ says that the elderly can continue to perform their social roles even when suffering from illness. The focus of health is strictly related to the overall functionality of the individual, defined as the ability to manage their own lives or take care of themselves. The elderly are considered healthy when they are able to carry out their activities alone, independently and autonomously, even if they have diseases.

In response to questioning about whether getting old is good or bad, two respondents referred to the degree of dependence and investment in care in old age, even in a somewhat stereotypical form.

"For us "poor old people", everything is fine. It all depends on what the younger people want". (E1)

The first (E1) refers to the reduction of functional capacity in a resigned and dependent form. According to the empirical knowledge of the elderly, the compromises that arise with advancing chronological age make them more fragile, and therefore decision-making and even the activities that they were once able to perform are assigned to younger members of the community.
"In some ways I think it's bad... Because I'm going through what my mother told me about. When we're born we get special treatment by everyone, go, go, you're a teenager, you're young... When you start getting old, you go back to being a child. Isn't that right? You go back to being a child!”. (E13)

It is well known that the progressive functional decline that accompanies longevity brings a greater need for care, as E13 describes. However, it is worth reflecting further on this as part of this line of analysis, so that, as Almeida ${ }^{22}$ points out, "the practice of care provided to the elderly does not turn into an infantilizing process, it must be differentiated, humane and respectful".

B3. Gradual reduction in the ability to work: "You just can't work anymore, can you?"

The perception of the elderly riverside dwellers revealed a particular representation of the value assigned to the physical performance of labor. Unlike in urban communities, riverine work is essentially manual and is not restricted by the retirement process itself, but more to the capacity of an individual to work and his or her contribution to the family and community as a labor source. Work for these people is a great revealer of their individual quality, and this perception was expressed in some discourses:

"I don't have the strength to work. Do you know what I mean?". (E1)

'It's not great because there are some jobs I can't do, do you, do you know what I mean? [...] Because we live in the country, you see? So it's heavy work.". (E8)

A study by Silva et al., ${ }^{5}$ conducted in a social center for the elderly, found that aging was concretely perceived and associated with the decline of physical strength, which led to the loss of working capacity. Considering the great value assigned to work in riverine communities, responsible in turn for feelings of productivity and utility, this perspective can be seen in the reports 
of the elderly persons in reference to the decline in working capacity related to aging.

"Because, in my opinion as we get older, we aren't able to do anything, no work, right? There are people who are still bealthy, they still work, do a lot of jobs, like me, before this. Pick açai, or palm hearts, all kinds of thing ... Now people say I just want to get up to eat [...]". (E12)

In the same context, when asked about their perceptions of work, one of the interviewees recognized their limitations and, as a result of these, described optimizing their functional capabilities, unveiling an optimistic, healthy and successful aging process.

"Let's say ten years ago I was working. If I had to carry something heavy, I'd carry something even heavier, wouldn't I? But not today. But I can't stop, can I? I can't stop working, but I have to find a smarter way of doing it. And that's how I feel good about myself, I'm still working, still pushing myself, but I'm not neglecting myself [...]”. (E7)

According to Teixeira \& Neri, ${ }^{23}$ successful aging is linked to the personal perception of the possibilities of adaptation to changes resulting from aging, and associated conditions. Thus, the elderly must adapt to changes both at a biological and psychological level, finding solutions to their living conditions.

\section{Perception anchored to coping strategies: "We have} to respect old age"

Regarding the adjustment to this new phase of life, in their discourses the elderly riverside dwellers referred to respect, in the sense of being cautious and readjusting their lives when faced with their perceived limitations, to achieve a healthy old age.

"[... what we have to have is ... a little bit of care and respect for our old age. Because if we, for example, don't look after ourselves, we get older and we die sooner [...]”. (E14)
"Getting old is normal, now, I've told my friends, we have to respect old age. If we abuse it, we'll suffer the consequences $[. .]$.$” . (E7)$

Reading between the lines of dialogue it was possible to identify the difficulty the elderly felt in being seen as people with limitations, mainly physical. Considering the environment that surrounds them and the ingrained everyday riverine activities that are performed during a lifetime and that require physical fitness, this idea is natural. In terms of this adjustment, Silva et al. ${ }^{5}$ highlighted the value of a family support network. For the authors, family support for the elderly is very important for the maintenance of functional capacity, and to prevent damage and accidents, while maintaining a good quality of life.

D. Respect for the mainstays of old age

D1. Family support network: "I stay here and wait for them to come back."

With regard to the family support model in this phase of life, it was noted that some of the elderly persons attributed difficulties in aging because of the distance and the absence of their relatives, as can be seen:

"Getting old is hard for us, because, you know, my daughters are far away. And my daughter-in-law has her things to do here, so it's difficult for me". (E4)

Other knowledge verbalized by the elderly reinforced the importance of family and indicated that their family members, especially children, sons and daughters-in-law, and grandchildren, worry about and care for them with love and care. They therefore feel protected and supported, as can be seen in this statement:

"Thanks to God and Our Lady my old age has been good. I have my children and grandchildren, and they live here in front or beside me... They really take care of me, I'm so happy to be near my children, but even if they lived far away, I have my husband, who has already taken care of me a lot and still does it today". (E13) 
According to Almeida et al., in old age, the role of the family is of fundamental importance for the support of the elderly, in terms of providing both affection and protection. Silva et al. ${ }^{5}$ reinforced the idea that maintaining interpersonal coexistence contributes to the avoidance of loneliness and social isolation, which often affects the old age of individuals.

\section{D2. Religious and spiritual dimension: "I thank God} for all I bave"

In the majority of the dialogues, the elderly riverside dwellers demonstrated that religion is an essential component that permeates their everyday life. The representation of the religious/ spiritual is often incorporated into their discourse, giving value to divine blessing and thanksgiving, which reinforces how important it is to believe in something higher in this stage of life.

"The life we have here isn't enough. I thank God a lot, you know? I thank God above everything, because we receive everything from his hand. Because he has given me these 60 years. I never thought I'd live to 60, because in my life I've had a few scrapes". (E9)

"My old age, thanks to God, has been good [...]". (E13)

Contrastingly, the religiosity of these elderly persons also shaped the way the process of growing old is perceived, assuming a role of providing guidance in life, as observed:

"We grow old the way God wants!". (E9)

This religious support has a major influence in this phase of life, as all the elderly persons surveyed demonstrated affinity and/or engagement with some kind of religious activity or practice in the riverside community, whether of the catholic or evangelical protestant faith. The culture of religious practice is extremely strong among these people, and includes values such as keeping Sunday sacred, a value cultivated within families from childhood to the present day.
Corroborating the findings of other studies, ${ }^{7,8,24}$ it was noted that old age has an intimate relationship with religiosity in various dimensions, and is particular to each life context. Regarding this issue, Sarmiento \& Lima Filho ${ }^{25}$ described how elderly persons acquire and strengthen their spirituality in a long life of chores and labor, of sacrifice and suffering. Therefore, in general, the religious-aging binomial represents a very important aspect in the lives of the elderly and therefore should not be neglected.

E. Respect for the end of life: "We go as far as we can, and then we die"

In the view of Polleto et al., ${ }^{26}$ human life is made up of possibilities, choices, and conceptions of the world, but has a limit. According to the authors, it is constructed and developed over the years, although an awareness of its finitude is always present.

According to Py \& Trein,${ }^{27}$ aging and death are unique life experiences, specific to each person. However, they are regulated by social and cultural patterns that define the significance of each of these human experiences, in the specificity of a time and a place in the history of humanity.

In the discourse of the elderly riverside dwellers, it became clear that death, as well as aging, is considered to be a natural process. In the discourse of two participants, for example, an authentic knowledge was revealed that showed that the elderly persons perceived and accepted death as a certainty.

\section{"... It's like death. Ah, because I'm not going to die! You're always going to die. Aren't you?". (E6) \\ "[...] because we can't go back, [..., we keep getting older until we die". (E10)}

Due to the relevance of this subject to the panorama of gerontological studies and considering the results achieved, it is hoped that this study will contribute to a broadening of the scientific understanding of the aging process, as it is based 
in empirical knowledge constructed from the everyday experience of the elderly living in a variety of traditional contexts.

On the other hand, it is worth noting some limitations that may be addressed in future investigations into the subject, such as the type of sample used and the small sample size. As it is a non-probabilistic convenience sample the study does not allow the generalization of the results to all riparian elderly persons in the Amazon region. Therefore, further research using a larger number of elderly people, including the inhabitants of other Amazonian riverside communities, is recommended.

\section{FINAL CONSIDERATIONS}

The interest in conducting the present study was based on a scientific concern, with the aim of discovering the perception of Amazonian riverine elderly persons of the aging process. The action of giving voice to the riverside population determined the scope of the proposed objective of this study and allowed important empirical knowledge about this process to emerge, involving socio-cultural characteristics which differ from the urban context.

Overall, the group analyzed described aging in a heterogeneous manner. However, all saw it as a process anchored to the naturalness of both life and death. Of the 14 elderly respondents, six associated old age with a stage of life with negative repercussions due to the appearance of functional disorders and limitations, and especially the reduction of availability for work. It can even be

\section{REFERENCES}

1. Beauvoir S. A velhice. São Paulo: Difusão Européia do Livro; 1990.

2. Moimaz SAS, Almeida MEL, Lolli LF, Garbin CAS, Saliba NA. Envelhecimento: análise de dimensões relacionadas à percepção dos idosos. Rev Bras Geriatr Gerontol 2009;12(3):361-75. seen that the majority, even with some limitations resulting from old age, have clear and well-defined coping strategies, such as the recognition of their limitations and family and religious support.

From the results achieved in this study, it was concluded that the elderly riverside dwellers have an individual perception of the subject, adjusted to their context. This suggests that the aging process along the riverbanks is perceived as the shared result of the experiences and empirical knowledge acquired and the environment that surrounds them. If on one hand territorial isolation, poverty, low educational levels and distance from social and health resources predominate; on the other, these individuals enjoy privileges such as greater contact with a bountiful natural environment in peace and tranquility and without strict standards of routine (characteristic of urban contexts); a network of wider social support, mainly represented by family relations, and a slower pace of life more favorable to older people, such as in rural communities.

Critical and reflective awareness of this issue must be encouraged. Finally, it is hoped that this study represents a step towards encouraging new research into riverside-dwelling elderly persons and can also contribute to health care based on the realities of these traditional populations.

\section{ACKNOWLEDGEMENTS}

The authors would like to thank the PostGraduate Support Program of the Higher Education Personnel Improvement Coordination (PROAP/CAPES).
3. Teixeira JS, Corrêa JC, Rafael CBS, Miranda VPN, Ferreira MEC. Envelhecimento e percepção corporal de idosos institucionalizados. Rev Bras Geriatr Gerontol 2012;15(1):613-24.

4. Almeida PM, Mochel EG, Oliveira MSS. O idoso pelo próprio idoso percepção de si e de sua qualidade de vida. Rev Kairós 2011;13(2):99-113. 
5. Silva EV, Martins F, Bachion MM, Nakatani AYK. Percepção de idosos de um centro de convivência sobre envelhecimento. REME Rev Min Enferm 2006;10(1):46-53.

6. Jardim VCFS, Medeiros BF, Brito AM. Um olhar sobre o processo do envelhecimento: a percepção de idosos sobre a velhice. Rev Bras Geriatr Gerontol 2006;9(2):25-34.

7. Lima CKG, Murai HC. Percepção do idoso sobre o próprio processo de envelhecimento. Rev Enferm UNISA 2005;6:15-22.

8. Biolchi CS, Portella MR, Colussi EL. Vida e velhice aos 100 anos de idade: percepções na fala dos idosos. Estud Interdiscip Envelhec 2014;19(2):583-98.

9. Papaléo Netto M. Gerontologia. São Paulo: Atheneu; 2002.

10. Rodrigues NO, Neri AL. Vulnerabilidade social, individual e programática em idosos da comunidade: dados do estudo FIBRA, Campinas, SP, Brasil. Ciênc Saúde Coletiva 2012;17(8):2129-39.

11. Paschoal SMP. Qualidade de vida na velhice. In: Freitas EV, Py L. Tratado de geriatria e gerontologia. Rio de Janeiro: Guanabara Koogan; 2011. Cap. 06. p. 99-106.

12. Rodrigues NC, Rauth J. Os desafios do envelhecimento no Brasil. In: Freitas EV, Py L. Tratado de geriatria e gerontologia. Rio de Janeiro: Guanabara Koogan; 2011. Cap. 12. p. 106-110.

13. Gil A. Como elaborar projetos de pesquisa. $4^{a}$ ed. São Paulo: Atlas; 2007.

14. Minayo MCS, organizadora. Pesquisa social: teoria, método e criatividade. 29ª ed. Petrópolis: Vozes; 2010.

15. Instituto Brasileiro de Geografia e Estatística. Síntese de indicadores sociais: uma análise das condições de vida da população brasileira [Internet]. Rio de Janeiro: IBGE; 2010 [acesso em 16 jan. 2015]. Disponível em: www.censo2010.ibge.gov.br

16. Bardin L. Análise de conteúdo. Lisboa: Edições 70; 2000.
17. Souza RF, Matias HA, Brêtas ACP. Reflexões sobre envelhecimento e trabalho. Ciênc Saúde Coletiva 2010;15(6):2835-43.

18. Zimerman GI. Velhice: aspectos biopsicossociais. Porto Alegre: Artmed; 2000.

19. Salmaso FV, Vigário PS, Mendonça LMC, Madeira M, Netto LV, Guimarães MRM, et al. Análise de idosos ambulatoriais quanto ao estado nutricional, sarcopenia, função renal e densidade óssea. Arq Bras Endocrinol Metab 2014r;58(3):226-31.

20. Rizzoli R, Reginster JY, Arnal JF, Bautmans I, Beaudart C, Bischoff-Ferrari H, et al. Quality of life in sarcopenia and frailty. Calcif Tissue Int 2013;93(2):101-20.

21. Moraes EN. Atenção à saúde do Idoso: aspectos conceituais. Brasília, DF: Organização PanAmericana da Saúde; 2012.

22. Almeida RSS. Representações sociais do idoso institucionalizado e influência na comunicação dos profissionais ajudantes de e ação direta [dissertação]. Castelo Branco: Instituto Politécnico de Castelo Branco, Escola Superior de Educação; 2014.

23. Teixeira IN, Neri, AL. Envelhecimento bemsucedido: uma meta no curso da vida. Psicol USP 2008;19(1):81-94.

24. Frumi C, Celich KLS. O olhar do idoso frente ao envelhecimento e à morte. Rev Bras Cienc Envelh Hum 2006;3(2):92-100

25. Sarmiento S, Lima Filho JB. A terceira idade na Pastoral da Criança: de bem com a vida. Curitiba: Pastoral da Criança; 2000.

26. Polleto S, Santin JR, Bettinelli LA. Dilemas do enfrentamento da morte de paciente Idoso. UNOPAR Cient Ciênc Juríd Empresariais 2014;13(2):49-55.

27. Py L, Trein F. Finitude e infinitude: dimensões do tempo na experiência do envelhecimento. In: Freitas EV, Py L. Tratado de geriatria e gerontologia. Rio de Janeiro: Guanabara Koogan; 2011. Cap. 121, p. 1350-58.

Received: June 10, 2015

Reviewed: November 8, 2015

Accepted: March 04, 2016 